Kristina Jauković Jocić ${ }^{1}$

Darjan Karabašević

Goran Jocić ${ }^{3}$

University Business Academy in Novi Sad,
ORIGINAL SCIENTIFIC ARTICLE doi: $10.5937 /$ ekonomika2003037J Received: June, 16. 2020. Accepted: July, 20. 2020.

Faculty of Applied Management, Economics and Finance, Belgrade

\title{
THE USE OF THE PIPRECIA METHOD FOR ASSESSING THE QUALITY OF E-LEARNING MATERIALS
}

\begin{abstract}
The weights of evaluation criteria could have a significant impact on the results obtained by using multiple criteria decision-making methods, which is why a number of methods have been proposed for determining them. In this article, the use of a newly proposed method for determining criteria weights, the PIvot Pairwise RElative Criteria Importance Assessment (PIPRECIA) method, is presented in the case of determining weights of criteria for assessing the quality of e-learning materials. The main goal is to define which criteria are the most important and have the crucial influence on the quality of e-learning material, as well as to demonstrate the applicability of the proposed method and the simplicity of its application.
\end{abstract}

Keywords: PIvot Pair-wise RElative Criteria Importance Assessment, PIPRECIA, SWARA, e-learning

JEL classification: C44, I29, M15

\section{ПРИМЕНА РІРRЕСІА МЕТОДЕ У ЕВАЛУАЦИЈИ КВАЛИТЕТА МАТЕРИЈАЛА ЗА ДАЉИНСКО УЧЕЊЕ}

\begin{abstract}
Апстракт
Тежине евалуационих критеријума могу имати значајан утииај на резултате добијене применом метода вишекритеријумског одлучиваға, те су предложене бројне методе за одређивање истих. У овом раду је приказана примена недавно предложене методе за дефинисање тежине критеријума под називом PIPRECIA (PIvot Pair-wise RElative Criteria Importance Assessment) метода, која је примењена у случају одређивања тежине критеријума за оцену квалитета материјала за даљинско учење. Основни ици је дефинисање критеријума који имају највећи значај и кључни утицај на квалитет материјала за далинско учење као и приказивање применьивости и једноставности примене наведене методе.
\end{abstract}

Кључне речи: PIvot Pair-wise RElative Criteria Importance Assessment, PIPRECIA, SWARA, даљинско учене

\footnotetext{
${ }^{1}$ kristina.jaukovic@mef.edu.rs, ORCID ID 0000-0002-7113-6269

${ }^{2}$ darjan.karabasevic@mef.edu.rs, ORCID ID 0000-0001-5308-2503

${ }^{3}$ goran.jocic@mef.edu.rs, ORCID ID 0000-0001-9863-974X
} 


\section{Introduction}

The use of information and communication technologies to disseminate knowledge is currently very topical. As a result, numerous e-learning platforms have become available, and numerous courses have been developed.

The emergence of more e-learning platforms as well as the emergence of a large number of courses has led to the need to assess their quality. Therefore, the definition of criteria for evaluating the quality of e-learning platforms, as well as determining the criteria for evaluating courses on them, has become a relevant and frequent topic. Apart from determining the criteria, as well as the sub-criteria for evaluation, determining their relative importance is also of current interest and significance.

In the field of multiple criteria decision-making (MCDM), a number of different approaches for determining the significance of criteria have been proposed so far (Popovic et al, 2019a; 2019b; Stanujkic et al., 2017b). Some of the current and prominent ones are the following: the AHP method (Saaty, 1980), the DEMATEL method (Gabus and Fontela, 1972), the Step-Wise Weight Assessment Ratio Analysis (SWARA) method (Kersuliene et al., 2010), the BWM method (Rezaei, 2015), and the FUCOM method (Pamucar et al., 2018).

Despite the fact that the SWARA method is a relatively newly-proposed MCDM method, it has been successfully used to solve many decision-making problems, such as: rational dispute resolution (Kersuliene et al., 2010), an architect selection (Kersuliene and Turskis, 2011), a supplier selection (Yazdani et al., 2016), personnel selection (Karabasevic et al., 2016a, 2016b), ERP system selection (Shukla et al., 2017), the evaluation of third-party reverse logistic provider (Mavi et al., 2017), the evaluation of solutions for reduction of transport pollution (Zavadskas et al., 2019), and the reduction of greenhouse gas emissions (Balki et al., 2020)

In the above-mentioned articles, the SWARA method is mainly used in combination with other MCDM methods, whereby it was used to determine the criteria weights.

In comparison with other methods intended for determining the criteria weights, the SWARA method is less complex for using, from the standpoint of the questioned persons (Stanujkic et al., 2015).

However, the first step in applying the SWARA method is a selection of criteria and their ranking according to their expected importance in descending order. This means that all participants in the evaluation have to agree on the expected importance of the criteria, which makes the SWARA method less applicable for solving some problems. Therefore, Stanujkic et al. (2017) proposed the adoption of the SWARA method that does not require the consent of the respondents regarding the expected significance of the criteria, under the name PIvot Pair-wise RElative Criteria Importance Assessment (PIPRECIA) method.

This feature makes the PIPRECIA method suitable for gathering the respondents' attitudes through the use of interactive questionnaires, which is why it was used in this article for determining the importance of the criteria for assessing the quality of e-learning materials. This is why the remaining part of the paper is organized as follows: in the first part, the computational procedure of the PIPRECIA method is presented and, in the second part, the criteria for assessing the quality of e-learning materials are presented. In the third part, a case study is given with the aim to determine the significances of the criteria. Finally, the conclusions are given. 


\section{The computational procedure of the PIPRECIA method}

The computational procedure of the PIPRECIA can be expressed as follows (Stanujkic et al., 2017a):

Step 1. Determine the relevant evaluation criteria and sort them in descending order, based on their expected significances.

Step 2. Starting from the second criterion, determine the relative importance $s_{j}$ as follows:

$$
s_{j}=\left\{\begin{aligned}
>1 & \text { when } C_{j} \succ C_{j-1} \\
1 & \text { when } C_{j}=C_{j-1} \\
<1 & \text { when } C_{j} \prec C_{j-1}
\end{aligned}\right.
$$

Step 3. Determine the coefficient $k_{j}$ as follows:

$$
k_{j}=\left\{\begin{array}{cc}
1 & j=1 \\
2-s_{j} & j>1
\end{array}\right.
$$

Step 4. Determine the recalculated weight $q_{j}$ as follows:

$$
q_{j}=\left\{\begin{array}{cc}
1 & j=1 \\
\frac{q_{j-1}}{k_{j}} & j>1
\end{array}\right.
$$

Step 5. Determine the relative weights of the evaluation criteria as follows:

$$
w_{j}=\frac{q_{j}}{\sum_{k=1}^{n} q_{k}}
$$

\section{The use of PIPRECIA method in group decision-making environment}

Many real decision-making problems require the involvement of several, or even more, decision-makers. In such cases, the resulting weights that represent the attitude of the group made up of $K$ decision-makers can be done in the following manner:

$$
\begin{aligned}
& w_{j}^{*}=\left(\prod_{k=1}^{K} w_{j}^{r}\right)^{1 / K} \\
& w_{j}=\frac{w_{j}^{*}}{\sum_{j=1}^{n} w_{j}^{*}}
\end{aligned}
$$

where $w_{j}^{*}$ denotes the geometric mean of the weights of criterion $j$ obtained by surveying respondents. 


\section{Criteria for assessing the quality of e-learning materials}

E-learning platforms and e-learning materials have been the subject of many studies. As a result of these studies, several criteria have been proposed, such as clear learning goals, objectives and outcomes, presentation of a domain in a meaningful and engaging way; nature of learning activities; elicitation of learners' understanding, and so on.

Hamtini and Fakhouri (2012) emphasized the following groups of criteria as the ones that cover the majority of the requirements for quality functioning of each e-learning platform, which are: social networking tools, productivity tools and software installation, administration tools and security, presentation tools and material distribution, and management features. All of these criteria are further elaborated on a certain number of sub-criteria that cast light on every feature important for good functioning of the e-learning platform. Beside the characteristics connected to the quality of the platform itself and its content, Cidral et al. (2018) involved one more dimension which engages the user aspect of the learning process.

With the aim of performing the comparison of the selected e-learning platforms, in the paper by Ouadoud et al. (2016) the utility and usability groups that involve a certain number of evaluation criteria are suggested. Büyüközkan et al. (2010) elicited the seven criteria appropriate for the evaluation of e-learning platforms and they are: right and understandable content, complete content, personalization, security, navigation, interactivity, and user interface. The extensive list of the criteria and sub-criteria pointed at the evaluation of the quality of the content of e-learning platforms is demonstrated in the paper of Al-Alwani (2014). As some of the significant articles devoted to this problem, the following can be mentioned: Alessi and Trollip (2001), Govindasamy (2002), Sun et al. (2008), Spratt and Lajbcygier, (2009), and so on.

\section{Case Study}

In this case study, the significance of the seven selected criteria was determined based on 24 successfully completed interactive questionnaires. The interactive questionnaires were designed to graphically and numerically present the significance of the criteria after entering respondents' attitudes, and thus allow respondents to eventually correct their attitudes. The interactive questionnaire was emailed to 40 addresses. Responses are obtained from 29 respondents, with 24 surveys filled-in correctly.

The criteria, which are defined on the basis of the examined literature previously presented, for assessing the quality of e-learning materials are as follows:

$-C_{1}$, Level of content,

- $C_{2}$, Presentation method,

$-C_{3}$, Teaching method,

$-C_{4}$, E-learning environment,

$-C_{5}$, Learning materials,

- $C_{6}$, Quality of multimedia content, and

$-C_{7}$, Group work and interactivity.

The responses, computational details, and weight obtained from the first of three randomly selected respondents are shown in Tables 1, 2 and 3. 
Table 1: The weight of criteria obtained from the first respondent

\begin{tabular}{llrrr}
\hline Criterion & \multicolumn{1}{l}{$s_{j}$} & \multicolumn{1}{l}{$k_{j}$} & \multicolumn{1}{l}{$q_{j}$} & \multicolumn{1}{l}{$w_{j}$} \\
\hline$C_{1}$ & & 1 & 1 & 0.16 \\
$C_{2}$ & 1.00 & 1.00 & 1.00 & 0.16 \\
$C_{3}$ & 0.90 & 1.10 & 0.91 & 0.14 \\
$C_{4}$ & 1.00 & 1.00 & 0.91 & 0.14 \\
$C_{5}$ & 1.00 & 1.00 & 0.91 & 0.14 \\
$C_{6}$ & 0.80 & 1.20 & 0.76 & 0.12 \\
$C_{7}$ & 1.10 & 0.90 & 0.84 & 0.13 \\
\hline & & & 6.33 & 1.00
\end{tabular}

Table 2: The weight of criteria obtained from the second respondent

\begin{tabular}{llrrl}
\hline Criterion & \multicolumn{1}{l}{$s_{j}$} & \multicolumn{1}{l}{$k_{j}$} & \multicolumn{1}{l}{$q_{j}$} & \multicolumn{1}{l}{$w_{j}$} \\
\hline$C_{1}$ & & 1 & 1 & 0.15 \\
$C_{2}$ & 0.90 & 1.10 & 0.91 & 0.13 \\
$C_{3}$ & 1.00 & 1.00 & 0.91 & 0.13 \\
$C_{4}$ & 1.00 & 1.00 & 0.91 & 0.13 \\
$C_{5}$ & 1.20 & 0.80 & 1.14 & 0.17 \\
$C_{6}$ & 0.90 & 1.10 & 1.03 & 0.15 \\
$C_{7}$ & 0.80 & 1.20 & 0.86 & 0.13 \\
\hline & & & 6.76 & 1.00
\end{tabular}

Table 3: The weight of criteria obtained from the third respondent

\begin{tabular}{lrrrl}
\hline Criterion & $s_{j}$ & \multicolumn{1}{c}{$k_{j}$} & \multicolumn{1}{l}{$q_{j}$} & \multicolumn{1}{l}{$w_{j}$} \\
\hline$C_{1}$ & & 1 & 1 & 0.16 \\
$C_{2}$ & 0.80 & 1.20 & 0.83 & 0.13 \\
$C_{3}$ & 0.90 & 1.10 & 0.76 & 0.12 \\
$C_{4}$ & 1.20 & 0.80 & 0.95 & 0.15 \\
$C_{5}$ & 1.00 & 1.00 & 0.95 & 0.15 \\
$C_{6}$ & 1.00 & 1.00 & 0.95 & 0.15 \\
$C_{7}$ & 1.00 & 1.00 & 0.95 & 0.15 \\
\hline & & & 6.38 & 1.00
\end{tabular}


The weights obtained from all respondents are presented in the Table 4, while the group weights calculated by using Eqs (5) and (6) are shown in the Table 5 and Figure 1.

Table 4: The weights obtained from all respondents includen in evaluation

\begin{tabular}{llllllll}
\hline & $C_{1}$ & $C_{2}$ & $C_{3}$ & $C_{4}$ & $C_{5}$ & $C_{6}$ & $C_{7}$ \\
\hline$R_{1}$ & 0.16 & 0.16 & 0.14 & 0.14 & 0.14 & 0.12 & 0.13 \\
$R_{2}$ & 0.15 & 0.13 & 0.13 & 0.13 & 0.17 & 0.15 & 0.13 \\
$R_{3}$ & 0.16 & 0.13 & 0.12 & 0.15 & 0.15 & 0.15 & 0.15 \\
$R_{4}$ & 0.14 & 0.14 & 0.13 & 0.13 & 0.16 & 0.14 & 0.16 \\
$R_{5}$ & 0.13 & 0.11 & 0.12 & 0.12 & 0.18 & 0.18 & 0.16 \\
$R_{6}$ & 0.15 & 0.13 & 0.13 & 0.16 & 0.16 & 0.14 & 0.14 \\
$R_{7}$ & 0.12 & 0.11 & 0.11 & 0.12 & 0.15 & 0.15 & 0.22 \\
$R_{9}$ & 0.12 & 0.16 & 0.16 & 0.16 & 0.14 & 0.12 & 0.15 \\
$R_{10}$ & 0.15 & 0.15 & 0.14 & 0.15 & 0.15 & 0.13 & 0.13 \\
$R_{11}$ & 0.16 & 0.13 & 0.12 & 0.13 & 0.13 & 0.16 & 0.16 \\
$R_{12}$ & 0.14 & 0.14 & 0.13 & 0.16 & 0.14 & 0.16 & 0.14 \\
$R_{13}$ & 0.13 & 0.11 & 0.10 & 0.15 & 0.16 & 0.16 & 0.18 \\
$R_{14}$ & 0.17 & 0.12 & 0.12 & 0.13 & 0.16 & 0.16 & 0.15 \\
$R_{15}$ & 0.14 & 0.16 & 0.14 & 0.13 & 0.13 & 0.15 & 0.15 \\
$R_{16}$ & 0.13 & 0.12 & 0.14 & 0.15 & 0.15 & 0.15 & 0.15 \\
$R_{17}$ & 0.13 & 0.13 & 0.15 & 0.16 & 0.15 & 0.15 & 0.13 \\
$R_{18}$ & 0.13 & 0.16 & 0.16 & 0.16 & 0.15 & 0.12 & 0.12 \\
$R_{19}$ & 0.17 & 0.15 & 0.15 & 0.15 & 0.15 & 0.12 & 0.12 \\
$R_{20}$ & 0.14 & 0.16 & 0.15 & 0.15 & 0.15 & 0.12 & 0.14 \\
$R_{21}$ & 0.15 & 0.14 & 0.14 & 0.15 & 0.15 & 0.13 & 0.16 \\
$R_{22}$ & 0.16 & 0.16 & 0.14 & 0.14 & 0.14 & 0.13 & 0.13 \\
$R_{23}$ & 0.15 & 0.15 & 0.13 & 0.14 & 0.16 & 0.13 & 0.13 \\
$R_{24}$ & 0.13 & 0.13 & 0.16 & 0.14 & 0.16 & 0.14 & 0.14 \\
\hline
\end{tabular}

Table 5: The group weights of the criteria for assessing the quality of e-learning materials

\begin{tabular}{|c|c|c|c|c|}
\hline & Criterion & $w_{j}$ & $w_{j}$ & Rang \\
\hline$C_{1}$ & Level of content & 0.144 & 0.145 & 3 \\
\hline$C_{2}$ & Presentation method & 0.137 & 0.138 & 6 \\
\hline$C_{3}$ & Teaching methods & 0.133 & 0.134 & 7 \\
\hline$C_{4}$ & E-learning environment & 0.143 & 0.143 & 4 \\
\hline$C_{5}$ & Learning materials & 0.150 & 0.151 & 1 \\
\hline$C_{6}$ & Quality of multimedia content & 0.141 & 0.142 & 5 \\
\hline \multirow[t]{2}{*}{$C_{7}$} & Group work and interactivity & 0.147 & 0.148 & 2 \\
\hline & & 0.994 & 1.000 & \\
\hline
\end{tabular}


As it can be concluded from the table 5, the most significant criterion is the criterion denoted as $C_{5}$, 'Learning materials', followed by the criteria $C_{7}$ and $C_{1}$.

Figure 1: The group weights of the criteria for assessing the quality of e-learning materials

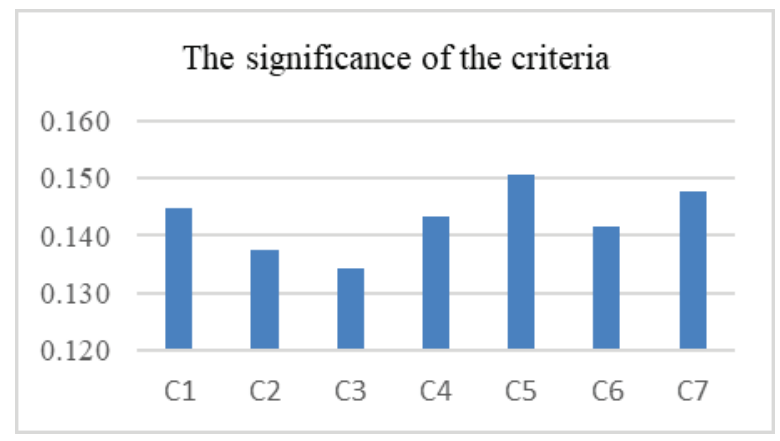

\section{Conclusion}

E-learning platforms, as well as e-learning materials, have been the subject of many studies. In order to assess their quality, the determination of the weights of the evaluation criteria is of great importance. In this paper, the PIPRECIA method was successfully applied for the purpose of the determination of the weights.

Therefore, based on the conducted research, two basic conclusions can be drawn.

The first conclusion relates to the importance of the criteria and states: Based on the examined group, the most important criterion is 'Learning materials', followed by the criteria 'Group work and interactivity', and 'Level of content'. Based on the research conducted, the least significant criterion is 'Teaching methods'.

The second conclusion concerns the application of the PIPRECIA method in order to determine the significance of the criteria. This method has already been applied with interactive questionnaires to determine the relevance of the criteria. The conducted research confirms its applicability with interactive questionnaires, especially when respondents have support for its usage.

\section{References}

Al-Alwani, A. (2014). Evaluation criterion for quality assessment of E-learning content. E-Learning and Digital Media 11(6), 532-542.

Alessi, S.M. \& Trollip, S.R. (2001). Multimedia for learning: methods and development. Boston, MA: Allyn and Bacon.

Balki, M. K., Erdoğan, S., Aydın, S., \& Sayin, C. (2020). The optimization of engine operating parameters via SWARA and ARAS hybrid method in a small SI engine using alternative fuels. Journal of Cleaner Production, 120685. 
Büyüközkan, G., Arsenyan, J., \& Ertek, G. (2010). Evaluation of e-learning web sites using fuzzy axiomatic design based approach. International Journal of Computational Intelligence Systems, 3(1), 28-42.

Cidral, W. A., Oliveira, T., Di Felice, M., \& Aparicio, M. (2018). E-learning success determinants: Brazilian empirical study. Computers \& Education, 122, 273-290.

Gabus, A., \& Fontela, E. (1972). World problems, an invitation to further thought within the framework of DEMATEL. Battelle Geneva Research Centre: Geneva, Switzerland.

Govindasamy, T. (2002). Successful implementation of e-learning pedagogical considerations. Internet and Higher Education, 4, 287-299.

Hamtini, T. M., \& Fakhouri, H. N. (2012). Evaluation of open-source e-Learning platforms based on the Qualitative Weight and Sum approach and Analytic Hierarchy Process. In Proceedings of the International Multi-Conference Society, Cybernetics and Informatics (pp. 1-7).

Karabasevic, D., Stanujkic, D., Urosevic, S., \& Maksimovic, M. (2016a). An Approach to Personnel Selection Based on SWARA and WASPAS Methods. BizInfo (Blace) Journal of Economics, Management and Informatics, 7(1), 1-11.

Karabasevic, D., Zavadskas, E. K., Turskis, Z., \& Stanujkic, D. (2016b). The framework for the selection of personnel based on the SWARA and ARAS methods under uncertainties. Informatica, 27(1), 49-65.

Kersuliene, V. \& Turskis, Z. (2011). Integrated fuzzy multiple criteria decision making model for architect selection. Technological and Economic Development of Economy, 17(4), 645-666.

Kersuliene, V., Zavadskas, E. K., \& Turskis, Z. (2010). Selection of rational dispute resolution method by applying new step-wise weight assessment ratio analysis (SWARA). Journal of business economics and management, 11(2), 243-258.

Mavi, R. K., Goh, M., \& Zarbakhshnia, N. (2017). Sustainable third-party reverse logistic provider selection with fuzzy SWARA and fuzzy MOORA in plastic industry. The International Journal of Advanced Manufacturing Technology, $1-18$.

Ouadoud, M., Chkouri, M. Y., Nejjari, A., \& El Kadiri, K. E. (2016, October). Studying and comparing the free e-learning platforms. In 2016 4th IEEE International Colloquium on Information Science and Technology (CiSt) (pp. 581-586). IEEE.

Pamucar, D., Stevic, Z., \& Sremac, S. (2018). A new model for determining weight coefficients of criteria in MCDM models: Full consistency method (FUCOM). Symmetry, 10(9), 393.

Popovic, G., Stanujkic, D., \& Karabasevic, D. (2019). A framework for the evaluation of hotel property development projects. International Journal of Strategic Property Management, 23(2), 96-107.

Popovic, G., Stanujkic, D., Brzakovic, M., \& Karabasevic, D. (2019). A multiplecriteria decision-making model for the selection of a hotel location. Land use policy, 84, 49-58.

Rezaei, J. (2015). Best-worst multi-criteria decision-making method. Omega, 53, 49-57. 
Saaty, T. L. (1980). Analytic Hierarchy Process. McGraw-Hill: New York, NY, USA.

Shukla, S., Mishra, P. K., Jain, R., \& Yadav, H. C. (2016). An integrated decision making approach for ERP system selection using SWARA and PROMETHEE method. International Journal of Intelligent Enterprise, 3(2), 120-147.

Spratt, C. \& Lajbcygier, P. (2009). E-learning technologies and evidence-based assessment approaches. London: Information Science Reference, IGI Global.

Stanujkic, D., Karabasevic, D., \& Zavadskas, E. K. (2015). A framework for the Selection of a packaging design based on the SWARA method. Inžinerine Ekonomika-Engineering Economics, 26(2), 181-187.

Stanujkic, D., Zavadskas, E. K., Karabasevic, D., Smarandache, F., \& Turskis, Z. (2017a). The use of the PIvot Pairwise RElative Criteria Importance Assessment method for determining the weights of criteria. Romanian Journal of Economic Forecasting, 20(4), 116-133.

Stanujkic, D., Zavadskas, E. K., Karabasevic, D., Turskis, Z., \& Keršulienė, V. (2017b). New group decision-making ARCAS approach based on the integration of the SWARA and the ARAS methods adapted for negotiations. Journal of Business Economics and Management, 18(4), 599-618.

Sun, P. C., Tsai, R. J., Finger, G., Chen, Y.-Y., \& Yeh, D. (2008). What drives a successfule-learning? An empirical investigation of the critical factors influencing learner satisfaction. Computers and Education, 50, 1183-1202.

Yazdani, M., Hashemkhani Zolfani, S., \& Zavadskas, E. K. (2016). New integration of MCDM methods and QFD in the selection of green suppliers. Journal of Business Economics and Management, 17(6), 1097-1113.

Zavadskas, E. K., Čereška, A., Matijošius, J., Rimkus, A., \& Bausys, R. (2019). Internal combustion engine analysis of energy ecological parameters by neutrosophic MULTIMOORA and SWARA methods. Energies, 12(8), 1415. 